\title{
Communication
}

\section{Gateway of Landfilled Plastic Waste Towards Circular Economy in Europe}

\author{
Juris Burlakovs ${ }^{1, * \mathbb{C}}$, Mait Kriipsalu ${ }^{2}$, Dmitry Porshnov ${ }^{3}$, Yahya Jani ${ }^{1}$, Viesturs Ozols ${ }^{3}$, \\ Kaur-Mikk Pehme ${ }^{2}$, Vita Rudovica ${ }^{4}$, Inga Grinfelde ${ }^{5}{ }^{\mathbb{D}}$, Jovita Pilecka ${ }^{5}$, Zane Vincevica-Gaile ${ }^{3}$, \\ Tsitsino Turkadze ${ }^{6}$, William Hogland ${ }^{1}$ and Maris Klavins ${ }^{3}$ \\ 1 Department of Biology and Environmental Science, Linnaeus University, SE-39231 Kalmar, Sweden; \\ yahya.jani@lnu.se (Y.J.); william.hogland@lnu.se (W.H.) \\ 2 Chair of Rural Building and Water Management, Estonian University of Life Sciences, F. R. Kreutzwaldi 5, \\ 51006 Tartu, Estonia; mait.kriipsalu@emu.ee (M.K.); kaur.pehme@emu.ee (K.-M.P.) \\ 3 Department of Environmental Science, University of Latvia, LV-1004 Riga, Latvia; \\ dmitrijs.porsnovs@lu.lv (D.P.); vipozols@gmail.com (V.O.); zane.gaile@lu.lv (Z.V.-G.); \\ maris.klavins@lu.lv (M.K.) \\ 4 Department of Analytical Chemistry, University of Latvia, LV-1004 Riga, Latvia; witaaa@gmail.com \\ 5 Department of Environmental Engineering and Water Management, Latvia University of Life Sciences and \\ Technologies, LV-2001 Jelgava, Latvia; inga.grinfelde@llu.lv (I.G.); jovita.pilecka@llu.lv (J.P.) \\ 6 Department of Chemical Technologies, Akaki Tsereteli State University, Kutaisi 4600, Georgia; \\ cici1000@mail.ru \\ * Correspondence: juris.burlakovs@lnu.se or juris@geo-it.lv; Tel.: +371-28469044
}

Received: 12 February 2019; Accepted: 22 April 2019; Published: 7 May 2019

check for updates

\begin{abstract}
For decades, significant work has been conducted regarding plastic waste by dealing with rejected materials in waste masses through their accumulation, sorting and recycling. Important political and technical challenges are involved, especially with respect to landfilled waste. Plastic is popular and, notwithstanding decrease policies, it will remain a material widely used in most economic sectors. However, questions of plastic waste recycling in the contemporary world cannot be solved without knowing the material, which can be achieved by careful sampling, analysis and quantification. Plastic is heterogeneous, but usually all plastic waste is jointly handled for recycling and incineration. Separation before processing waste through the analytical approach must be applied. Modern landfill mining and site clean-up projects in contemporary waste management systems require comprehensive material studies ranging from the macro-characterization of waste masses to a more detailed analysis of hazardous constituents and properties from an energy calorific standpoint-where, among other methods, thermogravimetric research coupled with life cycle assessment (LCA) and economic assessment is highly welcomed.
\end{abstract}

Keywords: circular economy; landfill mining; Plasticene; plastic waste; sorting; thermogravimetry

\section{Introduction: Plastic as a Material and Waste}

Plastic is widely used in industry, domestic, chemical engineering, construction and many other applications. The most important problem of plastic materials is that many of them degrade slowly and, as particles decrease in size, the problem becomes less visible but remains the main concern. No doubt everyone has seen plastic throughout the environment; its accumulation is of particular in oceans [1]. Degradation involves a range of physical and chemical processes, photodegradation, melting, etc., depending on the chemical composition of a material. However, environmental concerns are crucial nowadays. Scientists point out that we live in the Plasticene era [1,2], where geologists already find plastic conglomerates as deposits. Furthermore, the ocean biota are overwhelmed with 
plastic, both in water and biomass. Solutions for plastic waste are widely discussed-the first is to substitute; the second is to recycle sorted waste or reuse waste for energy. Furthermore, there is a huge amount of landfilled historical waste that is hard to sort and preliminary separation while investigating properties during landfill mining is compulsory.

Recycling and recovery, minimization of consumption of the landfilled waste are extremely important; however, striving for 'beyond zero waste' is challenging for today and the future [3]. There are more than half a million dump sites just in Europe, where a plethora of plastic waste is buried and forgotten by the linear economy [4].

\section{Concerns, Challenges and Solutions in Plastic Waste Treatment}

Challenges. With the growth in population and economic development, the production of municipal solid waste in Europe and worldwide presents high-risk or irreversible changes in the environment through the replenishment of resources and the diffuse spread of contamination in ecosystems, oceans and soils. How to deal with this problem is a task for all nations; however, it is important to split the problem into smaller parts, and one of the solutions is that plastic, together with other materials, might be employed as an alternative energy resource by implementing the 'waste-to-energy' concept [5-7]. This is already being regulated by the European Union (EU) Parliament directive on waste and is becoming more and more popular [8]. Moreover, it provides the diversification of waste processing options [9].

Recycling. In assessing the end-of-life management solutions of plastics, there is no doubt that the best possible approach is recycling, while it must be taken into consideration that only $15-20 \%$ of all plastic waste can be effectively recycled using conventional technologies [10]. Solutions that do not lead to the disintegration of plastic's polymeric structure (e.g., landfilling or uncontrolled dumping) are categorically undesirable due to actual or potential environmental pollution with microplastics [11]. While comparing the disintegrating methods of plastic waste treatment-incineration and pyrolysis/gasification - the results of a life cycle assessment (LCA) point to pyro-gasification or pyrolysis as the preferable methods [12,13].

Pyro-Gasification. Among the major problems hampering the implementation and wide use of waste material pyro-gasification, the high diversity and heterogeneity of waste materials should be considered. Different thermal behavior of various waste leads to very complex processes in a reactor: some compounds decompose in a melted state, others melt without decomposition, while other constituents decompose without melting. Furthermore, the decomposition characteristics of some compounds can impact the decomposition of others [10]. Polymers and synthetic resins are giant organic molecules with various properties of density, shear strength, etc.; as the size of the molecule rises, the melting or softening point increases-such materials become stronger and more rigid. Thus, to advance the processing of municipal waste materials containing plastic, there is a need to increase the understanding of the thermal transformation process of plastic waste materials. This knowledge is especially valuable considering the need to develop pyrolysis/gasification technologies [14-16].

Resource Recovery. Nevertheless, thermal methods are not the only solutions. As for the upcoming century, one of the biggest challenges is to provide mankind with relevant and sufficient resources. Recovery options of secondary resources play a significant role [17]. Industrial processes developed to regain minerals for the production of commodities in a circular economy have become ever more important in the EU and worldwide. This led to the development of the landfill mining (LFM) concept, which constitutes an important technological toolset of processes that regains resources and redistributes them. Simultaneously reduction of environmental contamination spread and other threats for human health possibly emerging from former dump sites and landfills is done [3,18]. 'Classical LFM' is a useful technology to discover hidden resources and look at the big picture of resources from the local, regional and global perspectives. It is called the 'beyond zero waste' concept, where mankind, instead of conquering space and the abyssal plains to conduct mining in the deepest oceans 
on the Earth, is starting with the reuse of historically dumped materials—of which plastic waste is a significant part [19].

Landfill Research. A landfill is a complex mixture of organic and inorganic waste such as contaminated soil, organic materials, oily sludge from car washes, plastic, etc. [20]. It contains extremely heterogeneous materials in organic and inorganic forms and usually there is a lack of information about its composition, volume and physical chemical properties [21,22]. Therefore, an analytical toolset is needed to establish physical and chemical properties to find suitable methods for recycling and recovering if landfill resources are to be mined. First of all, a geological investigation has to be performed-sampling for landfill mining characterization studies has been evaluated in several works [22-25]. The most common categories of landfilled waste are as follows: soft plastic, rigid plastic, wood, paper, ferrous metals, nonferrous metals, ceramics, textile, rubber, stones, glass and unidentified material (fine particles of waste that cannot be identified by visual inspection) [26,27].

Environmental Concerns about Nanoplastics. Environmental concerns appear with use of nano-sized materials including plastics and polymers [28]. Critical evaluation of human and environmental risks posed by these nanomaterials, especially those with a high production volume, requires analysis. This is because nanomaterials are materials that combine nano-sizes and high chemical reactivity. Nanomaterials pass treatment systems and accumulate in unpredictable ways in biomass [29]. There is an urgent need for broad and integrated studies that address the risks of engineered nanomaterials and other emerging pollutants, including their impacts on waste composition, to consider them for landfill mining and the recovery of valuables [30], as well as the recovery potential of the nanomaterial itself.

The future hypothesis is that a portion of ancient waste, including plastics, might achieve important potential that can be referred to as the 'reserves' or 'bank account' of nowadays for the future of the circular economy.

\section{Thermogravimetry as a Promising Method in Plastic Waste Decomposition}

The only way to permanently eliminate plastic waste is by destructive thermal treatment such as combustion or pyrolysis. However, it must be considered that recycling is not a way to eliminate final disposal, but only an approach that allows the final disposal to be postponed [31]. Thermochemical waste processing methods such as pyrolysis and/or gasification are often viewed as advanced waste-to-energy approaches. This point of view must be considered as outdated today, when we are trying to build up circular cycles of materials. Simple waste-to-energy is an approach of the 20th century that must be viewed as a way to return resources that today are considered as waste, and that cannot be recycled in a simpler way, back into the cycle, by using thermal distillation and fractionation. The main problem limiting the pyrolysis and gasification of plastic waste is the presence of halogens in the composition of some plastics. Halogens may act as acid-forming substances causing damage to technical equipment. In the case of pyrolysis to liquid fuels, halogens act as pollutants that make the resulting fuel unusable [32]. Furthermore, halogens can become a source of persistent organic pollutants, some of which are very well studied [33], while others are almost unknown [34]. The decomposition of halogen-containing polymers strongly differs from the decomposition of 'clean' plastic materials (Figure 1).

The dechlorination of polyvinylchloride (PVC) takes place at significantly lower temperatures than the decomposition of other plastics, while the development of fluorine-containing species occurs at much higher temperatures. First of all, these qualities may be used to sort out unwanted chemical elements (especially chlorine) from feedstock by a multistage thermal process with precise temperature control. Secondly, it gives the opportunity to control feedstock quality in automated regime, using a very simple and cheap method, called thermogravimetry, by using decomposition maximums specific for halogenated plastics as indicators of the presence of unwanted elements $[16,35]$.

The thermal decomposition or co-gasification of plastic waste with coal and biomass has been studied and the conversion efficiencies of waste polyethylene (PE) and polyethylene terephthalate (PET) were determined [36]. The paradigmatic change of perception of municipal waste from simply 
waste to an opportunistic form of energy appears to be promising. For example, in the United Arab Emirates, where fossil fuels are very cheap and tax-free, the question of sustainable energy creation from waste has been addressed by policy makers [37]. Business ventures to recover waste for energy or for petrochemical fuels have appeared for sorted plastic feedstock (such as PE, PET, polypropylene (PP), polystyrene (PS), and polyvinylchloride (PVC)), because of their predominance (>50\%) in packaging.

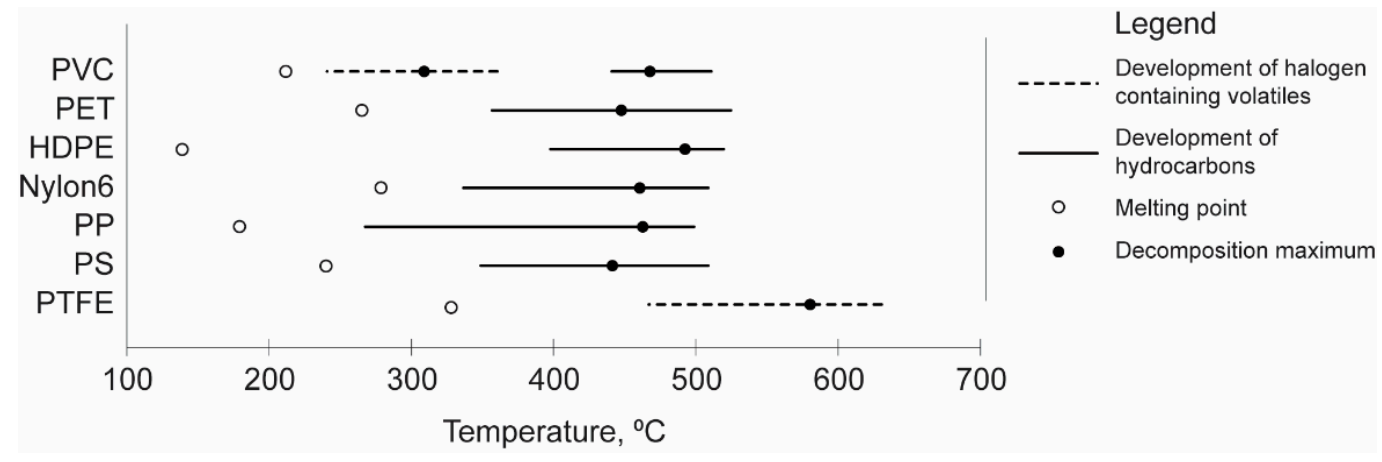

Figure 1. Decomposition temperature of various polymers.

Thermogravimetry as a Research Method. Gasification could diminish environmental hazards and pressure on landfills, increase energy outputs and could be expanded for LFM excavated waste [38-40]. The analytical tool to study the thermal decomposition of organic materials, including plastic [41,42], can be performed under atmospheric, inert conditions, or in oxygen is a thermogravimetric analysis. This tool can be used to describe the combustion and pyrolysis of combustible materials and their mixtures [42] as well as the thermal behavior of plastic-for example, thermal susceptibility and flammability [43], melting processes during the thermal treatment, etc. However, the high heterogeneity of waste plastic compositions can be considered a problem, depending on the region, country, season and many other factors. The high heterogeneity of plastic waste samples hampers the use of thermal decomposition studies on specific municipal waste samples as well as the extrapolation possibilities of the obtained results.

Thermal decomposition in a nitrogen atmosphere usually occurs in a range of temperatures $\left(400-500^{\circ} \mathrm{C}\right)$. The decomposition of natural rubber is observed earlier at $300^{\circ} \mathrm{C}$. The decomposition of the most widespread fluorine organic polymer requires a temperature of $480{ }^{\circ} \mathrm{C}$ to $585^{\circ} \mathrm{C}$. The potential opportunity to take away problematic elements from mixed plastic waste using precise temperature control (in the range of $375-385^{\circ} \mathrm{C}$ ) is attractive, while the interval of $470-480{ }^{\circ} \mathrm{C}$ is appropriate for the pyrolysis of plastic waste without initiation of the development of fluorine containing volatiles. Significant amounts of stable carbon form due to the presence of rubbers, PVC and PET in feedstock; therefore, heating methods that are not disturbed by the formation of carbon, e.g., inductive heating, are preferable for use in these technologies.

Examples of Thermogravimetry. Polyamide polymers known under the market name nylons are the group of polymers mainly used as synthetic textiles. The material analyzed by us, nylon 6 , is one of the most significant representatives of this group in the world's market. As it is shown in Figure 2, nylon 6 undergoes one-staged complete decomposition, which can be significantly affected by an oxidative environment. In nitrogen, the process occurs at $400-510{ }^{\circ} \mathrm{C}$ and reaches the maximum intensity at 463 ${ }^{\circ} \mathrm{C}$. An oxidative atmosphere initiates a very slow decomposition substage at $300-400{ }^{\circ} \mathrm{C}$ with $\Delta \mathrm{m}$ equal to $5 \%$, divides the main decomposition process in multiple substages, reduces its intensity and shifts the stabilization temperature up to $530{ }^{\circ} \mathrm{C}$. 

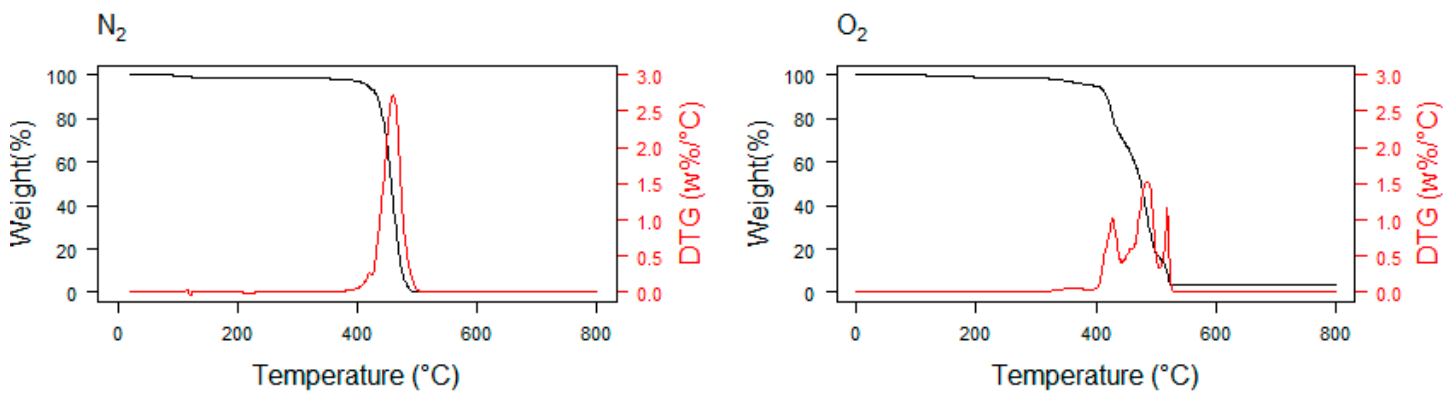

Figure 2. Decomposition of synthetic polyamide nylon 6 in nitrogen (on the left) and in oxygen (on the right).

Another example, shown in Figure 3, is of polytetraflourethylene (PTFE), also known as teflon/Gore-Tex. This is very stable polymer due to the strong C-F bond shielded by a highly electronegative fluorine atom [44]. In nitrogen, PTFE completely decomposes at the temperature interval of $480-630^{\circ} \mathrm{C}$ with a maximum at $586^{\circ} \mathrm{C}$ and a pronounced secondary maximum at $610^{\circ} \mathrm{C}$. An oxidative atmosphere shifts the beginning of decomposition to a higher temperature $\left(500{ }^{\circ} \mathrm{C}\right)$, strongly increases the intensity of the reaction, reduces the intensity of the secondary maximum and reduces the temperature of stabilization to $610^{\circ} \mathrm{C}[16]$.
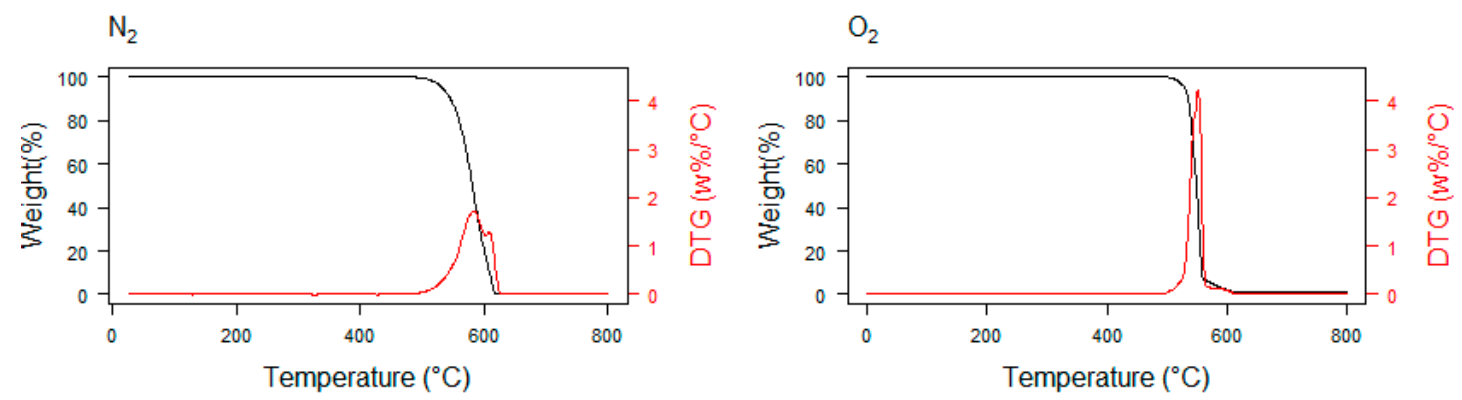

Figure 3. Decomposition of polytetraflourethylene (PTFE) in nitrogen (on the left) and in oxygen (on the right).

An oxidative environment has different impacts on the decomposition of plastic materials. Pyrolysis without oxidation seems to be much simpler and easier to manage than oxidative pyrolysis, and elimination of the presence of oxygen is very important not only considering the quality of the resulting pyrolysis products, but also considering the simplicity of the operation of the pyrolysis equipment $[15,16]$.

If gasification is the best solution, it will be shown with the time; however, small- to medium-scale gasification plants might be the best solution from an economic-environmental point of view as waste landfilling and recycling facilities nowadays are centralized. The decentralization and transformation of closed small to medium dumps and the implementation of local to regional gasification (or co-gasification) facilities that might work simultaneously with landfill-mined old waste and new sorted material represent new options to be exploited [14].

\section{Discussion on Economic Background}

Plastic waste creates $30-50 \%$ of landfilled waste. Because of the high heterogeneity of the plastic mixed waste in closed historical landfills, only thermal methods might appear attractive for the clean-up and possible recycling of waste in the transformation of waste to energy, waste to oils and waxes, waste to syngas, biochar and other useable materials. Another physical problem is increased moisture and dirt coupled with tiny degraded plastic particles. Finally, from an economic point of view, it should be noted that China has already banned the import of plastic waste and, therefore, all the waste 
exporters are currently looking for alternative markets, including large exporters such as the USA and Europe. This ban will lead to saturated markets and price decreases, which will greatly influence European recycling industries. Morgan Stanley and the Wall Street Journal reported that $87 \%$ of plastic waste in the EU was exported to China. The UK industry currently ships about 4.5 million tons of its waste to China. This includes around 494,000 tons of plastic waste and 1.4 million tons of recovered paper. Germany exported around 800,000 tons of plastic to China in 2017, and 1.2 tons during previous years. USA also exported tremendous amounts of plastic before the ban. In addition, the Chinese ban could result in more virgin plastic consumption. It could shift about $2 \%$ of global polyethylene plastics supply from recycled to new plastic materials. According to Morgan Stanley, China is already increasing its imports of virgin plastics-it imported $19 \%$ of virgin polyethylene and reduced its scrap polyethylene imports by $11 \%$ in 2017. The USA plastic industry is preparing for this shift-four new plants will begin annual production of 3.6 million tons of polyethylene. On the other hand, it was calculated that the municipal solid waste buried in old landfills of China and the energy embedded in the buried plastic waste amount to 1.37 billion tons of standard coal equivalent, which is $38 \%$ of the total annual energy consumption of China (3.62 billion tons of standard coal in the year 2012) [45].

Important circular priorities, due to their interpretation in different business environments (e.g., repair, remanufacture, repurpose), are dependent on the development state of the country. Overall, the circular transition takes time and political will [4].

\section{Conclusions}

Energetic utilization of reclaimed landfill material in conventional waste-to-energy facilities is generally possible, even if incineration went out of fashion some time ago. The necessity to re-cultivate old landfill sites will increase in the future, predominantly driven by factors such as ecology and urban planning. Modern landfill mining and site clean-up projects in contemporary waste management systems require comprehensive material studies ranging from the macro-characterization of waste masses to more detailed analyses of hazardous constituents and properties from an energy calorific standpoint, where thermogravimetric research coupled with LCA and economic assessment is highly welcomed. All the properties of plastic's original status are usually changed due to physical, chemical and biological influence over time. Moisture, impurities (even after special cleaning) and ash are the problems to be solved for recovery of LFM plastic waste in a circular economy. Therefore, extensive studies of landfill waste have been performed in the Baltic States, Sweden, the USA, Benelux countries and elsewhere. In the future, if large clean-up projects are planned through LFM processing, the use of thermogravimetry is important to estimate calorific values as well as the thermal conversion process in itself, upscaling the data to simulation.

Gasification is not a competitor of recycling, but LFM waste after the removal of inert material, recyclable metals, glass and paper-pre-processing and after-processing-must increase the amount of recyclables in a circular economy. Additionally, many end-of-life plastic waste, wood residues and paper can serve as a good, high energy feedstock for gasification since they cannot be sorted out and recycled otherwise. An additional benefit is the availability of small-scale plants eligible for gasification when other solutions are economically impractical.

Author Contributions: All the Co-authors contributed in the production of the whole article. Co-authors M.K. (Maris Klavins), D.P., V.O., V.R., Z.V.-G. from University of Latvia worked in thermogravimetrical experimental research and prviding analytical information together with analysis. Support of the colleagues prof. M.K. (Mait Kriipsalu) and K.-M.P. came mostly in the fields of waste management, where they actively collaborate with Linnaeus University-the Main Author and his colleagues W.H. and Y.J. Paramount importance is the work with literature-I.G. and her assistant J.P. gave significant input in Introductory as well as discussion parts.

Funding: This research was funded by European Regional Development Fund (ERDF) project 1.1.1.1/16/A/050 "Variable fuel gasification for municipal solid waste recovery", Interreg South Baltic CONTRA project, Swedish Institute LASUWAMA.

Conflicts of Interest: The authors declare no conflict of interest. 


\section{References}

1. Bottero, J.Y.; Auffan, M.; Borschnek, D.; Chaurand, P.; Labille, J.; Levard, C.; Masion, A.; Tella, M.; Rose, J.; Wiesner, M.R. Nanotechnology, global development in the frame of environmental risk forecasting. A necessity of interdisciplinary researches. C. R. Geosci. 2015, 347, 35-42. [CrossRef]

2. New Scientists. The Daily Newspaper. 28 January 2015. Plastic Age: How It's Reshaping Rocks, Oceans and Life. By Christina Reed. Available online: https://www.newscientist.com/article/mg22530060-200-plasticage-how-its-reshaping-rocks-oceans-and-life/ (accessed on 21 January 2019).

3. Burlakovs, J.; Jani, Y.; Kriipsalu, M.; Vincevica-Gaile, Z.; Kaczala, F.; Celma, G.; Ozola, R.; Rozina, L.; Rudovica, V.; Hogland, M.; et al. On the way to 'Zero Waste' management: Recovery potential of elements, including rare earth elements, from fine fraction of waste. J. Clean. Prod. 2018, 186, 81-90. [CrossRef]

4. Horvath, B.; Mallinguh, E.; Fogarassy, C. Designing business solutions for plastic waste management to enhance circular transitions in Kenya. Sustainability 2018, 10, 1664. [CrossRef]

5. Santibañez-Aguilar, J.E.; Ponce-Ortega, J.M.; Betzabe González-Campos, J.; Serna- González, M.; El-Halwagi, M.M. Optimal planning for the sustainable utilization of municipal solid waste. Waste Manag. 2013, 33, 2607-2622. [CrossRef] [PubMed]

6. Brunner, P.H.; Recberger, H. Waste to energy-Key element for sustainable waste management. Waste Manag. 2015, 37, 3-12. [CrossRef] [PubMed]

7. Zhao, L.; Giannis, A.; Lam, W.Y.; Lin, S.X.; Yin, K.; Yuan, G.A.; Wang, J.Y. Characterization of Singapore RDF resources and analysis of their heating value. Sustain. Environ. Res. 2016, 26, 51-54. [CrossRef]

8. Gug, J.; Cacciola, D.; Sobkowicz, M.J. Processing and properties of a solid energy fuel from municipal solid waste (MSW) and recycled plastics. Waste Manag. 2015, 35, 283-292. [CrossRef] [PubMed]

9. Othman, S.N.; Noor, Z.Z.; Abba, A.H.; Yusuf, R.O.; Hassan, M.A.A. Review on life cycle assessment of integrated solid waste management in some Asian countries. J. Clean. Prod. 2013, 41, 251-262. [CrossRef]

10. Buekens, A. Introduction to Feedstock Recycling of Plastics; Feedstock Recycling and Pyrolysis of Waste Plastics; Wiley Series: Hoboken, NJ, USA, 2006; pp. 3-41.

11. Andrady, A.L. The plastic in microplastics: A review. Mar. Pollut. Bull. 2017, 119, 12-22. [CrossRef] [PubMed]

12. Al-Salem, S.M.; Evangelisti, S.; Lettieri, P. Life cycle assessment of alternative technologies for municipal solid waste and plastic solid waste management in the Greater London area. Chem. Eng. J. 2014, 244, 391-402. [CrossRef]

13. Shonfield, P. LCA of Management Options for Mixed Waste Plastics; WRAP: Banbury, UK, 2008.

14. Klavins, M.; Bisters, V.; Burlakovs, J. Small scale gasification application and perspectives in circular economy. Environ. Clim. Technol. 2018, 22, 42-54. [CrossRef]

15. Porshnov, D.; Ozols, V.; Ansone-Bertina, L.; Burlakovs, J.; Klavins, M. Thermal decomposition study of major refuse derived fuel components. Energy Procedia 2018, 147, 48-53. [CrossRef]

16. Porshnov, D.; Ansone-Bertina, L.; Ozols, V.; Burlakovs, J.; Klavins, M. Thermogravimetric study of municipal waste plastics considering perspectives of waste pyro-gasification. SGEM Renew. Energy Sources Clean Technol. 2018. [CrossRef]

17. Bhatnagar, A.; Kaczala, F.; Burlakovs, J.; Kriipsalu, M.; Hogland, M.; Hogland, W. Hunting for valuables from landfills and assessing their market opportunities-A case study with Kudjape landfill in Estonia. Waste Manag. Res. 2017, 35, 627-635. [CrossRef]

18. Hogland, M.; Arina, D.; Kriipsalu, M.; Jani, Y.; Kaczala, F.; Salomão, A.L.; Orupõld, K.; Pehme, K.M.; Rudovica, V.; Denafas, G.; et al. Remarks on four novel landfill mining case studies in Estonia and Sweden. J. Mater. Cycles Waste 2018, 20, 1355-1363. [CrossRef]

19. Burlakovs, J.; Kriipsalu, M.; Klavins, M.; Bhatnagar, A.; Vincevica-Gaile, Z.; Stenis, J.; Jani, Y.; Mykhaylenko, V.; Denafas, G.; Turkadze, T.; et al. Paradigms on landfill mining: From dump site scavenging to ecosystem services revitalization. Resour. Conserv. Recycl. 2016, 123, 73-84. [CrossRef]

20. Jani, Y.; Kaczala, F.; Marchand, C.; Hogland, M.; Kriipsalu, M.; Hogland, W.; Kihl, A. Characterization of mined fine fraction and waste composition from a Swedish landfill. Waste Manag. Res. 2016, 34, 1292-1299. [CrossRef]

21. Hogland, W. Remediation of an old landfill site-soil analysis, leachate quality and gas production. Environ. Sci. Pollut. Res. 2002, 1, 49-54. [CrossRef] 
22. Kaartinen, T.; Sormunen, K.; Rintala, J. Case study on sampling, processing and characterization of landfilled municipal solid waste in the view of landfill mining. J. Clean. Prod. 2013, 55, 56-66. [CrossRef]

23. Hull, R.M.; Krogmann, U.; Asce, M.; Storm, F. Composition and characteristics of excavated materials from New Jersey landfill. J. Environ. Eng. 2005, 3, 478-490. [CrossRef]

24. Sormunen, K.; Ettala, M.; Rintala, J. Detailed internal characterization of twoFinish landfills by waste sampling. Waste Manag. 2008, 28, 151-163. [CrossRef]

25. Denafas, G.; Bucinskas, A. Feasibilities and perspectives for landfill mining in Lithuania. In Proceedings of the Linnaeus Eco-Tech'2014, Sweden, Kalmar, 24-26 November 2015.

26. Hogland, W.; Marques, M.; Nimmermark, S. Landfill mining and waste characterization: A strategy for remediation of contaminated areas. J. Mater. Cycles Waste 2004, 6, 119-124. [CrossRef]

27. Zuberi, M.S.; Ali, S.F. Greenhouse effect reduction by recovering energy from waste landfills in Pakistan. Renew. Sustain. Energy Rev. 2015, 44, 117-131. [CrossRef]

28. Burlakovs, J.; Pehme, K.-M.; Anne, O.; Kriipsalu, M.; Hogland, W. Remarks on novel case studies for integrated pollution prevention in Baltic Sea Region. SGEM Mar. Ocean Ecosyst. 2018. [CrossRef]

29. Klaine, S.J.; Koelmans, A.A.; Horne, N.; Carley, S.; Handy, R.D.; Kapustka, L.; Nowack, B.; von der Kammer, F. Paradigms to assess the environmental impact of manufactured nanomaterials. Environ. Toxicol. Chem. 2012, 31, 3-14. [CrossRef]

30. Tolaymat, T.; El Badawy, A.; Sequeira, R.; Genaidy, A. An integrated science-based methodology to assess potential risks and implications of engineered nanomaterials. J. Hazard. Mater. 2015, 298, 270-281. [CrossRef]

31. Geyer, R.; Jambeck, J.R.; Law, K.L. Production, use, and fate of all plastics ever made. Sc. Adv. 2017, 3, e1700782. [CrossRef]

32. Lopez-Urionabarrenechea, A.; de Marco, I.; Caballero, B.M.; Laresgoiti, M.F.; Adrados, A. Upgrading of chlorinated oils coming from pyrolysis of plastic waste. Fuel Proc. Technol. 2015, 137, 229-239. [CrossRef]

33. Buekens, A.; Cen, K. Waste incineration, PVC, and dioxins. J. Mater. Cycles Waste 2011, 13, 190-197. [CrossRef]

34. Lim, X. Tainted water: The scientists tracing thousands of fluorinated chemicals in our environment. Nature 2019, 566, 26-29. [CrossRef]

35. Porshnov, D.; Ozols, V.; Klavins, M. Thermogravimetric analysis as express tool for quality assessment of refuse derived fuels used for pyro-gasification. Environ. Technol. 2019. [CrossRef]

36. Kannan, P.; Al Shoaibi, A.; Srinivasakannan, C. Energy recovery from co-gasification of waste polyethylene and polyethylene terephthalate blends. Comput. Fluids 2013, 88, 38-42. [CrossRef]

37. Wu, C.; Williams, P.T. Pyrolysis-gasification of post-consumer municipal solid plastic waste for hydrogen production. Int. J. Hydrogen Energy 2010, 35, 949-957. [CrossRef]

38. Ahmed, I.I.; Gupta, A.K. Hydrogen production from polystyrene pyrolysis and gasification: Characteristics and kinetics. Int. J. Hydrogen Energy 2009, 34, 6253-6264. [CrossRef]

39. He, M.; Xiao, B.; Hu, Z.; Liu, S.; Guo, X.; Luo, S. Syngas production from catalytic gasification of waste polyethylene: Influence of temperature on gas yield and composition. Int. J. Hydrogen Energy 2009, 34, 1342-1348. [CrossRef]

40. Williams, P.T.; Slaney, E. Analysis of products from the pyrolysis and liquefaction of single plastics and waste plastic mixtures. Resour. Conserv. Recycl. 2007, 51, 754-769. [CrossRef]

41. Dunnu, G.; Maier, J.; Scheffknecht, G. Ash fusibility and compositional data of solid recovered fuels. Fuel 2010, 89, 1534-1540. [CrossRef]

42. Sever, A.S.; Atimtay, A.; Sanin, F.D. Comparison of fuel value and combustion characteristics of two different RDF samples. Waste Manag. 2016, 46, 217-224. [CrossRef]

43. Medic-Pejic, L.; Fernandes-Anez, N.; Rubio-Arrieta, L.; Garcia-Torrent, J. Thermal behaviour of organic solid recovered fuels (SRF). Int. J. Hydrogen Energy 2016, 41, 16556-16565. [CrossRef]

44. Beyler, C.L.; Hirschler, M.M. Thermal Decomposition of Polymers; SFPE Handbook of Fire Protection Engineering; Elsevier: Amsterdam, The Netherlands, 2002; pp. 110-131.

45. Zhou, C.; Fang, W.; Xu, W.; Cao, A.; Wang, R. Characteristics and the recovery potential of plastic wastes obtained from landfill mining. J. Clean. Prod. 2014, 80, 80-86. [CrossRef]

(C) 2019 by the authors. Licensee MDPI, Basel, Switzerland. This article is an open access article distributed under the terms and conditions of the Creative Commons Attribution (CC BY) license (http://creativecommons.org/licenses/by/4.0/). 